\title{
The Efficacy of Interferon-Alpha Treatment in Human T-Lymphotropic Virus Type-I-Associated Myelopathy
}

\author{
Tatsufumi NaKAMURA, Kohji SHIBAyama, Kunihiko NAGASATO, \\ Hidenori MATSUO, Mitsuhiro TSUJIHATA* and Shigenobu NAGATAKI
}

\begin{abstract}
We investigated the efficacy of interferon-alpha (IFN- $\alpha$ ) treatment in 5 patients with human T-lymphotropic virus type I (HTLV-I)-associated myelopathy (HAM). Treatment with IFN- $\alpha$ yielded clinical improvement of gait, and sensory and/or sphincter disturbance in 4 out of the 5 HAM patients. IFN- $\alpha$ treatment did not bring about uniform changes in lymphocyte subsets or anti-HTLV-I antibody titer of peripheral blood. Although the stimulation indexes to phytohemagglutinin, concanavalin $\mathbf{A}$, and pokeweed mitogen were decreased in the culture of the peripheral blood lymphocytes (PBL) in the 5 HAM patients before the treatment, the stimulation indexes to these mitogens were significantly increased except in 1 case after the IFN- $\alpha$ treatment. These changes were based primarily on the depression of the spontaneous proliferation of PBL without mitogen. These results appear to point out a very important phenomenon for the investigation of the pathogenesis of HAM.
\end{abstract}

Key words: HAM, Spontaneous proliferation, IFN- $\alpha$, Immunological marker

Human T-lymphotropic virus type I (HTLV-I)associated myelopathy (HAM) is characterized by slow progressive spastic paraplegia with urinary disturbance accompanied by anti-HTLV-I antibody in the serum and cerebrospinal fluid (CSF) (1). It was demonstrated that the viral genome detected in peripheral lymphocytes and CSF T cells of HAM patients is identical to that found in adult $\mathrm{T}$ cell leukemia patients $(2,3)$. Although the mechanisms by which HTLV-I infection causes chronic myelopathy still remain to be clarified, it is suggested that some immune mechanisms might be involved in the pathogenesis of HAM $(1,4-6)$.

Previously, we have reported that plasmapheresis is effective in treatment of patients with HAM (7). It is well known that with corticosteroid treatment HAM show clinical improvement (1). Here, we in- vestigated the effect of interferon-alpha (IFN- $\alpha$ ) treatment in patients with HAM. During the treatment, we studied the changes in immunological marker-lymphocyte subsets, anti-HTLV-I antibody, and the proliferative responses to several types of mitogens.

\section{SUBJECTS AND METHODS}

\section{Subjects}

Table 1 summarizes the clinical features of the 5 patients with HAM (1 man, 4 women; 28 to 67 years old). The diagnosis of HAM was based on the criteria described by Osame et al (1).

\section{Treatment with Interferon-alpha}

The 5 HAM patients were treated with interferonalpha (IFN- $\alpha$ ). IFN- $\alpha$, derived from human lymphoblastoid (HLBI, Sumiferon) (Sumitomo

This study was supported in part by Neuroimmunological Disease Research Committee grant from the Ministry of Health and Welfare of Japan, Tokyo

From First Department of Internal Medicine, Nagasaki University School of Medicine, Nagasaki and *School of Allied Medical Sciences, Nagasaki University, Nagasaki

Received for publication September 20, 1989; Accepted for publication May 30, 1990

Reprint requests should be addressed to Tatsufumi Nakamura, MD, First Department of Internal Medicine,

Nagasaki University School of Medicine, 7-1 Sakamoto-machi, Nagasaki 852, Japan 
Table 1. Clinical features in patients with human T-lymphotropic virus type I-associated myelopathy.

\begin{tabular}{|c|c|c|c|c|c|c|c|c|c|c|}
\hline \multirow{2}{*}{$\begin{array}{l}\text { Patient no } \\
\text { Age(yr)/Sex }\end{array}$} & \multirow{2}{*}{$\begin{array}{l}\text { Age of } \\
\text { onset }(\mathrm{yr}) / \\
\text { duration of } \\
\text { illness }\end{array}$} & \multirow{2}{*}{$\begin{array}{l}\text { Blood } \\
\text { transfusion }\end{array}$} & \multirow{2}{*}{$\begin{array}{l}\text { Initial } \\
\text { symptom/or } \\
\text { disturbance } \\
\text { of }\end{array}$} & \multicolumn{4}{|c|}{ Neurological findings } & \multirow{2}{*}{$\begin{array}{l}\text { sphincter } \\
\text { disturb. }\end{array}$} & \multirow{2}{*}{$\begin{array}{l}\text { Disability } \\
\text { grade }\end{array}$} & \multirow{2}{*}{$\begin{array}{l}\text { Dose of IFN- } \alpha(\text { IU* }) / \text { day } \\
\text { Duration (weeks) }\end{array}$} \\
\hline & & & & DTR & $\mathrm{PR}$ & $\begin{array}{l}\text { Muscle } \\
\text { tonus }\end{array}$ & $\begin{array}{l}\text { sensory } \\
\text { disturb. }\end{array}$ & & & \\
\hline \multirow[t]{2}{*}{ Case $134 / \mathrm{M}$} & $6 / 28$ & - & gait & $3+$ & + & spastic & - & + & 2 & $\begin{array}{l}3 \times 10^{6} ; 1 \mathrm{~W} \\
6 \times 10^{6} ; 1 \mathrm{~W} \\
9 \times 10^{6} ; 2 \mathrm{~W}\end{array}$ \\
\hline & $15 / 13$ & - & gait & $3+$ & + & spastic & - & + & 3 & $\begin{array}{r}1.5 \times 10^{6} ; 1 \mathrm{~W} \\
3 \times 10^{6} ; 2 \mathrm{~W} \\
6 \times 10^{6} ; 1 \mathrm{~W}\end{array}$ \\
\hline $328 / \mathrm{F}$ & $13 / 15$ & - & gait & $3+$ & + & spastic & + & + & 7 & $3 \times 10^{6} ; 4 \mathrm{~W}$ \\
\hline $467 / \mathrm{F}$ & $66 / 1$ & - & gait & $2+$ & + & spastic & + & + & 3 & $3 \times 10^{6} ; 4 \mathrm{~W}$ \\
\hline $550 / \mathrm{F}$ & $38 / 12$ & - & gait & $3+$ & + & spastic & - & + & 3 & $3 \times 10^{6} ; 4 \mathrm{~W}$ \\
\hline
\end{tabular}

$\mathrm{DTR}=$ deep tendon reflex, $\mathrm{PR}=$ pathologic reflex, ${ }^{*} \mathrm{IU}=$ international units

Pharmaceutical Co. Ltd., Osaka, Japan), was principally administered as a daily intramuscular injection of 3 million international units (IU) for 4 weeks. IFN- $\alpha$ was administered using a gradual increase method in some cases (case $1 ; 3$ to $9 \times 10^{6} \mathrm{IU}$, case $2 ; 1.5$ to $6 \times 10^{6} \mathrm{IU}$ ) (Table 1$)$.

Assessment of effect: The clinical endpoints selected for assessment of treatment were: time required for walking 3 to $30 \mathrm{~m}$; presence of deep tendon reflexes, clonus, pathologic reflexes, and effect on sensory and sphincter disturbance. Motor function was graded, based on the disability grade reported by Matsuo et al (7).

\section{METHODS}

\section{Lymphoblastoid transformation of peripheral blood}

Peripheral blood mononuclear cells were separated from heparinized venous blood by FicollConray density gradient centrifugation. After washing 3 times, $1 \times 10^{5}$ viable cells suspended in TC 199 supplemented with $20 \%$ fetal bovine serum were distributed in flat-bottom 96-well microplates and incubated with phytohemagglutinin (PHA; 20 $\mu \mathrm{g} / \mathrm{ml}$, Difco Laboratories, Detroit, MI), concanavalin A (ConA; $34 \mu \mathrm{g} / \mathrm{ml}$; Difco Laboratories), pokeweed mitogen (PWM; $20 \mu \mathrm{g} / \mathrm{ml}$, GIBCO, Grand Island, NY), or without mitogen at $37^{\circ} \mathrm{C}$ in a humid atmosphere of $95 \%$ air and $5 \% \mathrm{CO}_{2}$. The cell cultures were established in triplicate. After 48 $\mathrm{h}$ each culture was pulsed with $0.5 \mu \mathrm{Ci}$ of $\left[{ }^{3} \mathrm{H}\right]$ thymidine (New England Nuclear, Boston, MA) and harvested $24 \mathrm{~h}$ later on glass fiber filters with a semi-automatic multiple cell harvester (LABO MASH, Labo Science, Tokyo). Radioactivity (count per min; cpm) was measured in a liquid scintillation counter (LSC703, Aloka, Tokyo). Results were also expressed as stimulation indexes (SI; cpm in mitogen-stimulated culture/cpm in unstimulated culture). In 20 normal healthy controls, SI to PHA, ConA and PWM were $230.3 \pm$ 107.1, 182.1 \pm 97.3 , and 51.4 \pm 28.5 , respectively. And spontaneous proliferation (cpm in unstimulated culture) was $385.4 \pm 151.7$ in 20 normal healthy controls.

\section{Other tests}

Measurement of anti-HTLV-I antibody in sera was performed using enzyme-linked immunosorbent assay (ELISA; using Eitest-ATL of Eisai, Inc. Tokyo) (8) and Western blot analysis (9) using MT-2 cell lysate antigens (10). Determination of lymphocyte subsets of peripheral blood was carried out by a fluorescence-activated cell sorter (Spectrum III), using monoclonal antibodies (CD2, 3, 4, 8, 25, OKIaI and Leu 7, IIa).

\section{RESULTS}

The effect of IFN- $\alpha$ treatment

Treatment with IFN- $\alpha$ achieved clinical improvement in gait, and sensory and/or sphincter disturbance in 4 out of 5 HAM patients (Table 2). 
Table 2. Effect of IFN- $\alpha$ treatment in HAM patients.

\begin{tabular}{|c|c|c|c|c|c|c|c|c|c|c|}
\hline \multirow{3}{*}{$\begin{array}{l}\text { Patients no/ } \\
\text { Duration of } \\
\text { illness(yr) }\end{array}$} & \multicolumn{4}{|c|}{ Improvement $\Delta$} & \multicolumn{3}{|c|}{$\begin{array}{l}\text { Time(s) required to walk } \\
\text { distance }(\mathrm{sec})\end{array}$} & \multicolumn{2}{|c|}{$\begin{array}{l}\text { Changes in } \\
\text { disability grade }\end{array}$} & \multirow{3}{*}{ Effect* } \\
\hline & \multirow{2}{*}{ gait } & \multirow{2}{*}{$\begin{array}{l}\text { sensory } \\
\text { function }\end{array}$} & \multirow{2}{*}{$\begin{array}{l}\text { sphincter } \\
\text { function }\end{array}$} & \multirow{2}{*}{$\begin{array}{l}\text { subjective } \\
\text { feeling }\end{array}$} & \multirow{2}{*}{$\begin{array}{l}\text { Distance } \\
\text { walk (m) }\end{array}$} & \multicolumn{2}{|c|}{ Time } & \multirow[b]{2}{*}{ Before } & \multirow[b]{2}{*}{ After } & \\
\hline & & & & & & Before & After & & & \\
\hline Case $1 / 28$ & + & $\mathrm{N}$ & + & ++ & 30 & 17 & 16 & 2 & 2 & ++ \\
\hline $2 / 13$ & - & $\mathrm{N}$ & - & - & 30 & 23 & 24 & 3 & 3 & - \\
\hline $3 / 15$ & - & - & - & - & 3 & 20 & 10 & 7 & 7 & + \\
\hline $4 / 1$ & ++ & + & - & ++ & 10 & 18 & 7 & 3 & 2 & ++ \\
\hline $5 / 12$ & - & $\mathrm{N}$ & - & + & 30 & 25 & 21 & 3 & 3 & + \\
\hline
\end{tabular}

A For gait, sensory, sphincter and subjective improvement, $++=$ marked, $+=$ moderate, $-=$ no improvement. * = for effect,$++=$ good,$+=$ moderate, $-=$ no response, $\mathrm{N}=$ not involved

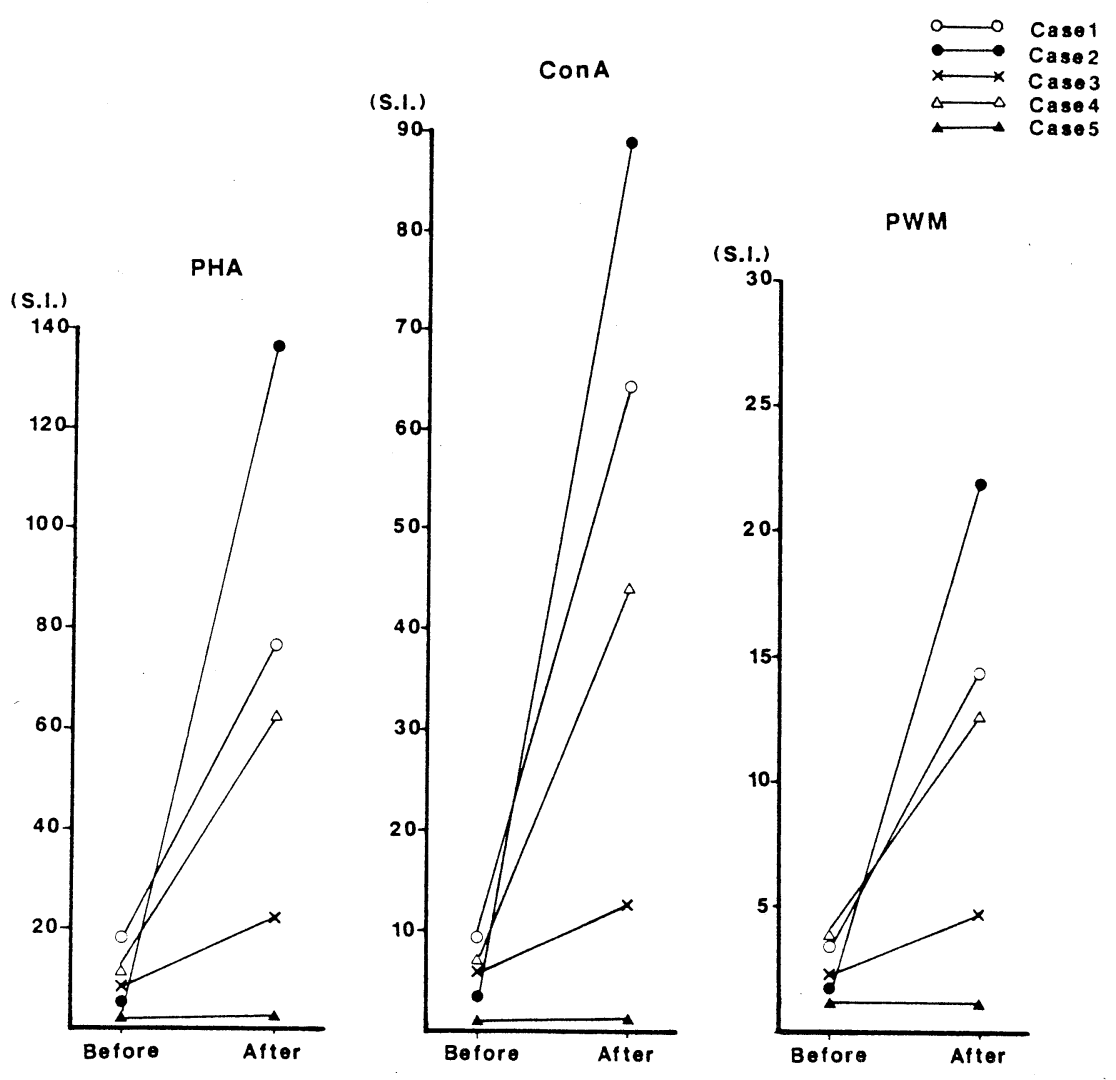

Fig. 1. Changes in lymphoblastoid transformation to mitogens in the treatment with IFN- $\alpha$. The stimulation indexes (S.I.) to PHA, ConA, and PWM were significantly increased except in case 5 after treatment IFN- $\alpha$. Before: before the treatment, After: after the treatment. 
Case 4 had a significant improvement of 1 grade in gait after treatment. In this case, the time required to walk $10 \mathrm{~m}$ was decreased from 18 to $7 \mathrm{~s}$. The assessment in case 1 was determined as a marked response because of the improvement in gait and sphincter disturbance even at the same disability grade during treatment. Cases 3 and 5, were assessed as moderate response, based on the decrease in the time required to walk 3 or $30 \mathrm{~m}$, respectively. However, no changes were recorded in deep tendon reflexes, pathologic reflexes, or clonus. The effect of the treatment did not correlate with the duration of illness.

\section{The changes in lymphoblastoid transformation during IFN- $\alpha$ treatment}

The stimulation indexes to PHA, ConA, and PWM were markedly depressed before the treatment. This phenomenon is related to the spontaneous proliferation of unstimulated lymphocytes in culture. As shown in Fig. 1, the treatment with IFN- $\alpha$ brought significant elevation of the stimulation indexes to these mitogens in 4 cases (all except case 5). These changes were based mainly on the depression of the spontaneous proliferation of PBL without mitogen from $4898 \pm 39,18731 \pm$ $3202,12909 \pm 3130,10235 \pm 940$, and $35716 \pm 3690$ to $1056 \pm 48,635 \pm 116,4217 \pm 646,1798 \pm 303$, and $10086 \pm 2027$, respectively (Fig. 2).
The changes in anti-HTLV-I antibody titer and lymphocyte subsets in the peripheral blood

IFN- $\alpha$ treatment did not uniformly change the lymphocyte subsets of the peripheral blood. The titers of anti-HTLV-I antibody in the sera (IgM, $\mathrm{IgG})$ were not altered remarkably after the treatment, although IgM anti-HTLV-I antibody was detected in all 5 patients. Furthermore, no change in the pattern of the bands of Western blot analysis of anti-HTLV-I antibodies was detected (data not shown).

\section{DISCUSSION}

In this report, we demonstrated that IFN- $\alpha$ was effective in the treatment in patients with HAM. IFN- $\alpha$ has antiviral and immunomodulating actions, and IFN- $\alpha$ treatment has been reported to be effective for some types of viral diseases or immune-mediated diseases. For example, Knobler et al reported that IFN- $\alpha$ treatment reduces exacerbation in 15 of 24 multiple sclerosis patients with an exacerbating-remitting course in a randomized, double-blind, placebo-controlled crossover study (11). It was demonstrated that intraventricular injection of IFN- $\alpha$ is effective for patients with subacute sclerosing panencephalitis (12). Dusheiko et al also elucidated that recombinant IFN- $\alpha$ treatment in patients with chronic hepatitis B produces a loss in HBsAg, hepatitis B virus DNA and DNA polymerase (13). Very recently, it was reported that IFN- $\alpha$ is an effective treatment in AIDS-related

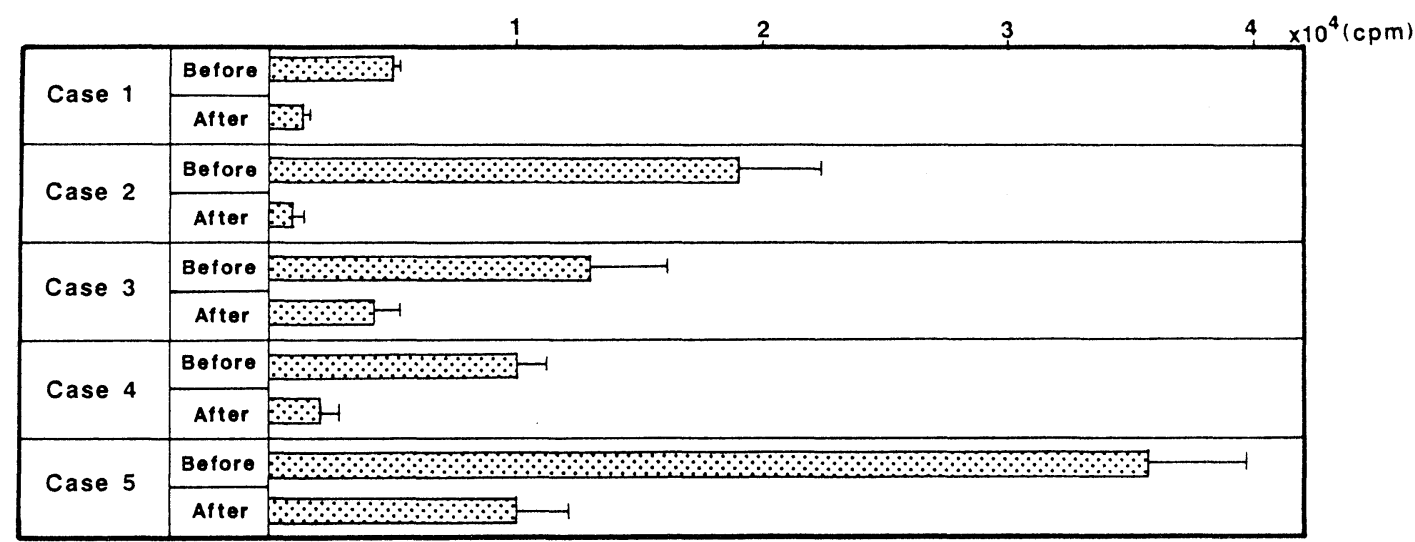

Fig. 2. Changes in spontaneous proliferation of the peripheral blood lymphocytes in the treatment with IFN- $\alpha$. The increased spontaneous proliferation of the peripheral blood lymphocytes was remarkably depressed after IFN- $\alpha$ treatment. Before: before the treatment, After: after the treatment. 
Kaposi's sarcoma $(14,15)$. The determination of effectiveness was based on the increase of OKT4-positive cells and the decrease in human immunodeficiency virus antigen.

In a previous report $(5,6)$, neither The abnormality of lymphocyte subsets of PBL in HAM patients previously documented $(5,6)$ was not altered by IFN- $\alpha$ treatment. Neither was the anti-HTLV-I antibody titer in the serum. Hirsch and Johnson also reported that the percentage of cells reacting to OKT3, OKT4, and OKT8 antibodies did not change significantly with unchanged proliferative responses to mitogens with long-term administration of recombinant IFN- $\alpha$ in multiple sclerosis (16). However, we demonstrated that the increased spontaneous proliferation of PBL was remarkably depressed after IFN- $\alpha$ treatment. The unusual increase of spontaneous proliferation of PBL reported by Itoyama et al (17) seems to be the most characteristic feature of the abnormal immunological findings in PBL of HAM patients. The depression of spontaneous proliferation of $\mathrm{PBL}$ after IFN- $\alpha$ treatment does not seem to be a toxic effect of IFN- $\alpha$ because the stimulation indexes to mitogens were significantly increased (except in one case) after IFN- $\alpha$ treatment. The mechanisms of the increased spontaneous proliferation of PBL in HAM patients are still not clarified. Itoyama et al mentioned that this phenomenon was probably a response to IL-2 through the expression of the IL-2 receptor (17). Sonoda et al suggested that the spontaneous proliferation of PBL culture was dependent on the cytotoxic $\mathrm{T}$-cell generated in the population of CD8-positive $\mathrm{T}$ cells (18). Alternatively, as Gazzolo and Duc Dodon revealed the direct stimulation of resting $\mathrm{T}$ lymphocytes by HTLV-I (19), the spontaneous proliferation of PBL might be the direct response of lymphocytes to HTLV-I itself. Previously, Yoshida et al reported that HTLV-I sequences are detected in samples of fresh peripheral blood lymphocytes in eight of nine patients with HAM (2). This suggests that the increased spontaneous proliferation of PBL might be related to the copy number of HTLV-I in the peripheral blood of patients with HAM.

The mechanism of the immunological and virological alterations resulting from IFN- $\alpha$ treatment in HAM patients is still unknown. In this study, IFN- $\alpha$ treatment in HAM caused a significant depression of the increased spontaneous proliferation of PBL, although the degree of change did not correspond with the effectiveness of IFN- $\alpha$ treatment. This fact seems to be a very important phenomenon for the investigation of the pathogenesis of HAM. Further studies of the investigation of immunological and virological aspects are now on going.

\section{REFERENCES}

1) Osame M, Matsumoto $M$, Usuku K, et al. Chronic progressive myelopathy associated with elevated antibodies to human T-lymphotropic virus type I and adult T-cell leukemia like cells. Ann Neurol 21: 117, 1987.

2) Yoshida M, Osame M, Usuku K, et al. Virus detected in HTLV-I associated myelopathy and adult T-cell leukemia are identical on DNA blotting. Lancet i: 1085 , 1987.

3) Nakamura $T$, Tsujihata $M$, Shirabe $S$, et al. Characterization of HTLV-I in a T-cell line established from a patient with myelopathy. Arch Neurol 46: 35, 1989.

4) Akizuki S, Nakazato O, Higuchi Y, et al. Necropsy findings in HTLV-I-associated myelopathy. Lancet i: 156, 1987.

5) Itoyama Y, Kira J, Fujii N, et al. Increases in helper inducer T-cells and activated T cells in HTLV-Iassociated myelopathy. Ann Neurol 26: 257, 1989.

6) Mori M, Kinoshita K, Ben $\mathrm{N}$, et al. Activated $\mathrm{T}$ lymphocytes with polyclonal gammopathy in patients with human T-lymphotropic virus type I-associated myelopathy. Ann Neurol 24: 280, 1988.

7) Matsuo $H$, Nakamura $T$, Tsujihata $M$, et al. Plasmapheresis in treatment of human T-lymphotropic virus type-I associated myelopathy. Lancet ii: 1109 , 1988.

8) Taguchi H, Sawada T, Fujishita H, et al. Enzyme-linked immunosorbent assay of antibodies to adult $\mathrm{T}$-cell leukemia-associated antigens. Gann 74: 185, 1983.

9) Laemmli UK. Cleavages of structural proteins during the assembly of the head of bacteriophage T4. Nature 27: 680, 1970.

10) Miyoshi I, Kubonishi I, Yoshimoto S, et al. Type C virus particles in a cord $\mathrm{T}$-cell line derived by co-cultivating normal human cord leukocytes and human leukemic T-cells. Nature 294: 770, 1981.

11) Knobler RL, Panitch SL, Braheny JC, et al. Systemic alpha-interferon therapy of multiple sclerosis. Neurology 34: 1273, 1984.

12) Panitch HS, Gomez-Plascencia J, Norris FH, et al. Subacute sclerosing panencephalitis: Remission after treatment with intraventricular interferon. Neurology 36: 562, 1986.

13) Dusheiko G, Dibisceglie A, Bowyer S, et al. Recom- 
binant leukocyte interferon treatment of chronic hepatitis B. Hepatology 5: 556, 1985.

14) De Wit R, Schattenkerk JKME, Boucher CAB, et al. Clinical and virological effects of high-dose recombinant interferon- $\alpha$ in disseminated AIDS-related Kaposi's sarcoma. Lancet ii: 1214, 1988.

15) Lane HC, Kovacs JA, Feinberg J, et al. Anti-retroviral effects of interferon- $\alpha$ in AIDS-associated Kaposi's sarcoma. Lancet ii: 1218, 1988.

16) Hirsch RL, Johnson KP. The effect of long-term administration of recombinant alpha-2 interferon on lymphocyte subsets, proliferation, and suppressor cell function in multiple sclerosis. J Interferon Res 6: 171, 1986.
17) Itoyama $Y$, Minato S, Kira J, et al. Spontaneous proliferation of peripheral blood lymphocytes increased in patients with HTLV-I-associated myelopathy. Neurology 38: 1302, 1988.

18) Sonoda S, Yashiki S, Usuku K, et al. HLA and immunological aspects of HTLV-I-associated myelopathy (HAM). in: HTLV-I and the Nervous System; Neurology and Neurobiology, vol. 51, Roman GC, Vernant JC, Osame M, Eds. Alan R. Liss, New York, 1989.

19) Gazzolo L, Duc Dodon M. Direct activation of resting T lymphocytes by human T-lymphotropic virus type I. Nature 326: 714, 1987. 